\title{
Audit and tax in the context of emerging technologies: A retrospective analysis, current trends, and future opportunities
}

Osama F. Atayah. College of Business, Abu Dhabi University. UAE dr.osamaatayah@gmail.com

Muneer M. Alshater. Faculty of Business, Middle East University. Jordan muneermaher@gmail.com

\begin{abstract}
This study aims to review the existing literature on audit and tax in the context of emerging technologies, besides providing future research agenda. A meta literature approach by combining bibliometric and content analysis was adopted to analyze 154 relevant English articles published in Scopus indexed journals, published over the last 35 years. Using RStudio, VOSviewer, and Microsoft Excel. Quantitative findings reveal that the USA is the top contributor and the most cited in the world. Brigham Young University, on the institutional level, is the most relevant affiliation. Concerning publication number, the Journal of Emerging Technologies in Accounting is the most relevant source. At the same time, the most cited source is the Decision Sciences journal. While the most prolific author is Miklos Vasarhelyi. Moreover, the emerging technologies, including big data, blockchain, and artificial intelligence, have significantly drawn accounting scholars interest from 2015 and thereafter. From the perspective of qualitative findings, the main focus shows that employing advanced technologies offers promising opportunities to mitigate the risk of tax evasion and enhance the auditors' efficiency. The content analysis reports two mainstreams tax and audit; each one is classified into three sub-streams, big data, artificial intelligence, and blockchain. This study contributes to present a clear and coherent understanding of the relevant exact literature and propose future research. However, the study review confines only on audit and tax fields, relying on the Scopus database.
\end{abstract}

Keywords: Audit, tax, bibliometric, emerging technologies, big data, artificial intelligence, blockchain. 


\section{INTRODUCTION}

The advent of Industry 4.0 has remarkably remodelled the accounting industry's operating style and reshaped the labour market's needed competencies. Currently, the profession witnesses a higher interest in assessing the current status and exploring its future (Moll \& Yigitbasioglu, 2019; Shaffer et al., 2020). Accordingly, accountants are struggling to preserve value-adding to the users of financial reports since the stakeholders' expectations from the accountant have increased to include using the advanced technologies efficiently and interpreting the financial information in a reliable and relevant way. Kirk and Rifkin (2020) investigated the impact of advanced technologies on accountant skills in the industry. Having analyzed 33,000 job posts in American and European countries, the authors have documented uncertainty and vogue concerning the accounting profession's future and emphasized practitioners' pivotal role to retain their skills up to date in emerging technologies. This includes accountants' technical skills, cognitive skills (technological, adaptability, interpretation, synthesis, prediction, and reflection skills), and behaviour skills.

The financial reports are the main output of the accounting process since they are the base for the internal and external users' economic decisions, and their reliability is vital in developing adequate and correct decisions (Kolsi \& Attayah, 2018). The auditors' role is significant to verify financial reports' fairness and increase financial reports' reliability. On the other hand, the tax represents one of the primary sources for the governments' income to finance their necessary expenditures and one of the major fiscal tools to control the economy. Thus, audit and tax draw individuals and firms interests; since it directly affects their investments decisions, income, and consumption behavior (Faccia \& Mosteanu, 2019). They have also stated that many taxpayers try to minimize their tax payment "tax evasion" by manipulating financial reports. The internal revenue agents are specifically responsible for audit and assess the taxpayer filing compliance with tax laws. This has led to conclude that the field of audit and tax is highly correlated and interrelated. Technological advancements have changed the nature and quality of the audit and tax profession.

Consequently, the topic has recently attracted the interest of scholars, policymakers, governments, and individuals. Notably, accounting scholars are still in the early stages to investigate the impact of advanced technologies on the accounting profession (Alles \& Gray, 2020; Pei \& Vasarhelyi, 2020; Schmitz \& Leoni, 2019; 
Tiberius \& Hirth, 2019). Thus, this study will shed light to investigate the available literature in the field of audit and tax in emerging technologies only.

Precisely, this study aims to offer a deep understanding and thorough insights into this field of knowledge. Namely, first, explore and analyze the extant academic contribution. Second, identify the current trend, systemize the available literature. Third, propose future research opportunities. Aiming to answer three main questions: 1. What are the key influential aspects of emerging technologies in audit and tax? 2. What are the key research streams of emerging technologies in audit and tax? 3. What is the needed research, and what are the future research directions?

This study contributes to the existing literature in several ways. First, it clearly and coherently identifies the emerging technologies' implication on audit and tax. Second, the bibliometric analysis offers a clear understanding of the previous and current research trends and offers a reliable understanding of this particular area of intellectual structure. Third, it identifies relevant future research opportunities. Furthermore, this study could be in favour of many stakeholders, i.e. the practitioners, legislative bodies in accounting, tax authorities, researchers, accounting educators, and higher education institutions.

The remaining study section structured as follows: the second section discusses the methodology, the third section discusses the results of the bibliometric analysis and content analysis, the fourth section presents the future research opportunities, and the last section presents the conclusions.

\section{METHODOLOGY}

This study uses the bibliometric approach to serve the study aims. Bibliometric, combined with content analysis, is increasingly becoming a well-recognized field among scholars (Koskinen et al., 2008). The following section thoroughly describes the data collection procedures, data refinement, and tools/instruments employed to conduct the study tests.

\subsection{Data source and data collection}

In line with Paltrinieri et al. (2020), figure (1) summarizes this study's methodological process. The Scopus database is well recognized for its broad coverage and reliability. The study uses online refinements and cursory 
examination from two researchers of each article to assure that the articles are sturdily and directly related to the study topic. The data of this study focuses on two essential and interrelated topics, the audit and tax.

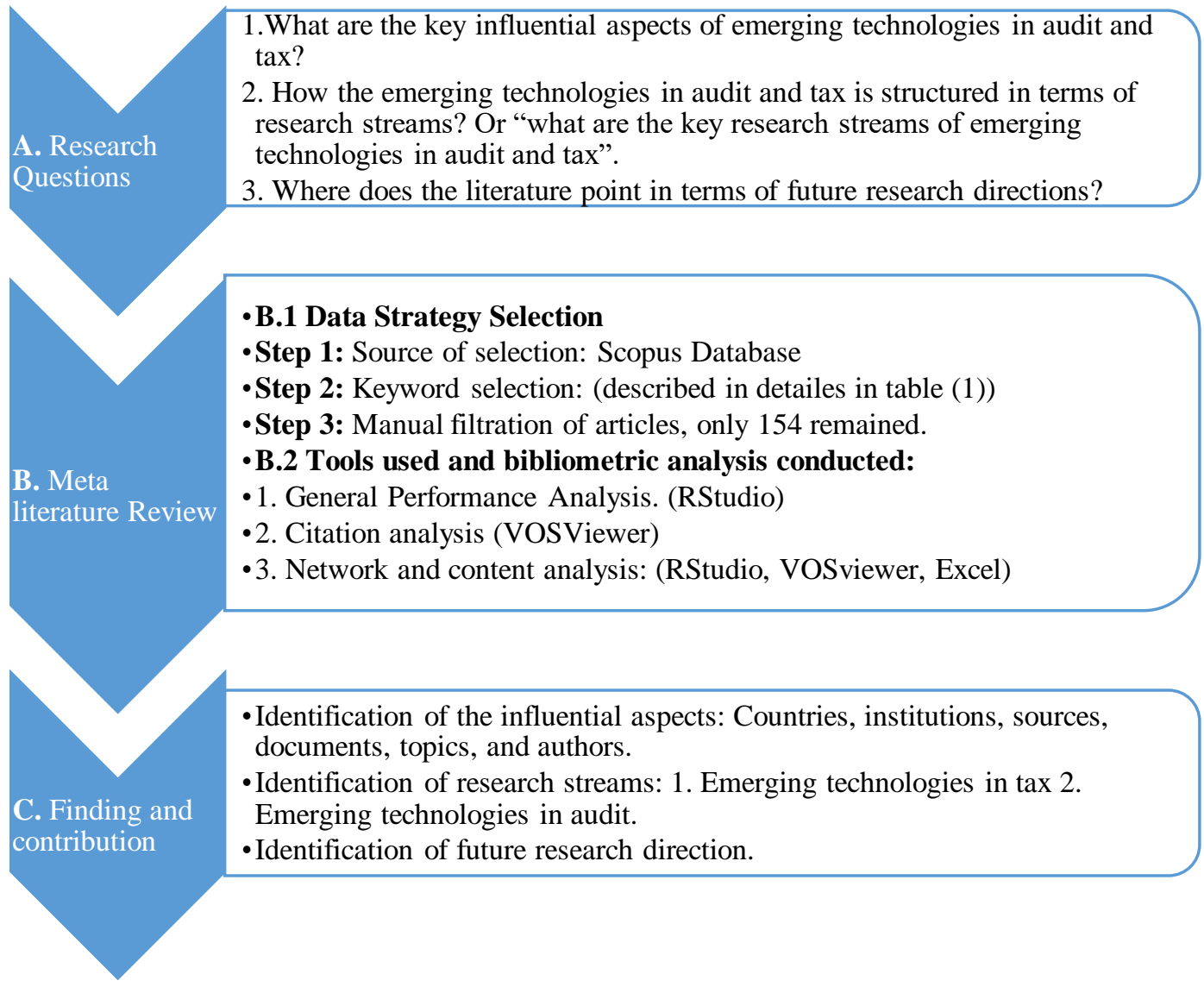

Figure 1. Methodological process

Table 1 thoroughly demonstrates the process of keywords selection. This study consults the Scopus database to extract the relevant documents. Having conducted the manual examination of each selected research paper, the study narrows its scope to the most 154 relevant papers.

\section{Description}

Exclusion brief

Total refined

TITLE-ABS-KEY ( taxes OR taxation OR tax OR audit OR ifrs OR gaap OR cpa OR "financial report*" OR "general audit* standard*" OR aaoifi OR "VAT" OR "financial fraud*" OR "big*four*" OR "financial statement* fraud*" OR "Annual report*" OR "external auditor*" OR "internal audit*" ) AND TITLE-ABS-KEY ( "big*data" OR bigdata OR "machine*learning*" OR "artificial intelligen*" OR "deep*learning*" OR "cloud*computing" OR "data*mining" OR "block*chain" OR "Blockchain" OR 


\begin{abstract}
"automated account* technolog*" OR "disruptive technolog*" OR "smart contract*" OR "collaborative databases" OR "natural language processing" OR "NLP" OR "Fuzzy logic" OR "Neural network models" OR "cognitive technolog*" OR "distributed ledger technology" OR "advance* technolog*" OR "fourth industr*" OR "industry 4.0" OR "collaborative platform*" OR "digital reporting*" OR "smart technolog*" OR "emerging technolog*" OR dlt OR "Intelligent visualization*" OR "expert system*" OR "Intelligent detection" OR "triple-entry accounting*" OR "cloud computing technolog*" OR "robot tax" ) AND ( LIMIT-TO ( DOCTYPE, "ar" ) OR LIMIT-TO ( DOCTYPE, "re" ) ) AND ( LIMIT-TO ( SUBJAREA , "BUSI" ) OR LIMIT-TO ( SUBJAREA, "SOCI" ) OR LIMIT-TO ( SUBJAREA, "ECON" ) OR LIMIT-TO ( SUBJAREA, "DECI" ) OR LIMIT-TO ( SUBJAREA, "MULT" ) ) AND ( LIMIT-TO ( LANGUAGE , "English" ) ) AND ( LIMIT-TO ( SRCTYPE , "j"))
\end{abstract}

Access

Types including both open access and others.

Years

Including all years from 1989 to August 2020.

0

We kept only the subject type (Social Sciences,

Subject area

Business, Management and Accounting, Decision

Sciences, Economics, Econometrics and Finance, and

Multidisciplinary).

Document type Limiting the documents to articles and review papers, while other types have been excluded.

\begin{tabular}{|l|}
\hline \\
Publication stage
\end{tabular}

We kept both of the final documents and articles in the press.

Source type

We kept the journals, excluded all other sources.

Language

We excluded all languages other than English.

Number of documents (After search refine)

Manual refinement: Manual exclusion of all irrelevant documents (231 documents have been excluded).

Final relevant literature

154

Table 1. Search description

\title{
2.2. Analysis and tools
}

The study uses RStudio, VOSviewer, and Microsoft Excel to answer the study questions efficiently and accurately. Rstudio has used general performance analysis to reveal the literature growth pattern, the most influential actors, citation structure, topic growth pattern, and topic trends analysis. VOSviewer enabled the researchers 
to reveal the network patterns between various literature actors and generate the keyword cartography. Excel was helpful to double-check the outcomes from the final dataset and was used to produce editable graphs and tables.

\section{RESULTS}

\subsection{General information and performance Analysis}

Table 2 provides a general overview of the collected data. There are 154 documents associated with 89 different journals; this indicates that the published documents are scattered over many journals, which counter the importance of being concentrated in a specialized academic outlet. However, from 361 authors, only 31 were single authors, and the collaboration index is 2.53 , which indicates a high trend of collaboration in this field, which could be due to the interdisciplinary nature of this topic; this is consistent with Schmitz \& Leoni (2019) study that the cooperation between accounting and IT scholars allows for a higher understanding of technological areas of accounting. According to the Scopus database classification, there are only four reviews in this field, which is considered low and encourages more contribution in this area.

\begin{tabular}{|l|c|}
\hline \multicolumn{1}{|c|}{ Description } & Results \\
\hline \multicolumn{1}{|c|}{ MAIN INFORMATION ABOUT DATA } & \\
\hline Timespan & $1986-2020$ \\
\hline Sources (Journals) & 89 \\
\hline Documents & 154 \\
\hline Average years from publication & 7.47 \\
\hline Average citations per documents & 11.05 \\
\hline Average citations per year per doc & 1.485 \\
\hline References & 5020 \\
\hline Article & \\
\hline
\end{tabular}




\begin{tabular}{|c|c|}
\hline Review & 3 \\
\hline \multicolumn{2}{|l|}{ DOCUMENT CONTENTS } \\
\hline Keywords Plus (ID) & 644 \\
\hline Author's Keywords (DE) & 398 \\
\hline \multicolumn{2}{|l|}{ AUTHORS } \\
\hline Authors & 361 \\
\hline Author Appearances & 389 \\
\hline Authors of single-authored documents & 31 \\
\hline Authors of multi-authored documents & 330 \\
\hline \multicolumn{2}{|l|}{ AUTHORS COLLABORATION } \\
\hline Single-authored documents & 31 \\
\hline Documents per Author & 0.427 \\
\hline Authors per Document & 2.34 \\
\hline Co-Authors per Documents & 2.53 \\
\hline Collaboration Index & 2.68 \\
\hline
\end{tabular}

Table 2. General Information

Figure 2 shows the distribution wise of the 154 articles and reviews published between 1986 and (Oct) 2020. The annual growth pattern was 7.92\%, which is a decent growth rate. Although the publication in this area had started in the 1980s, it has been of great interest and concern over the last five consecutive years. 


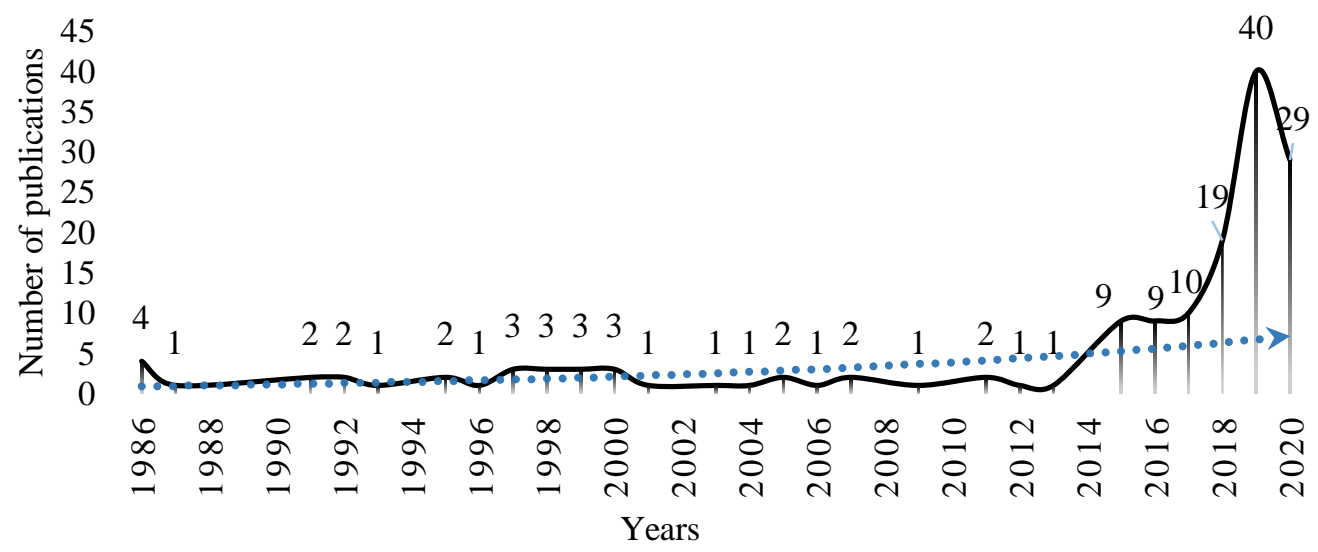

Figure 2. Annual production and growth pattern

The growth of articles was associated with a scientific community and countries. The entire countries that contributed to the field are 39 countries. Table 3 shows that the USA, China, and Australia have led this research area. The top five countries have contributed to $64 \%$ of the total published documents and hitting $71 \%$ of the total citations. Such results show that this topic's discussion is still in its infancy stage in the global scientific arena.

\begin{tabular}{|c|c|c|c|c|}
\hline Number & Country & Documents & Citations & Citation per document \\
\hline 1 & United States & 59 & 827 & 14.0 \\
\hline 2 & Australia & 12 & 200 & 16.7 \\
\hline 3 & China & 11 & 34 & 3.1 \\
\hline 4 & United Kingdom & 9 & 78 & 8.7 \\
\hline 5 & Spain & 7 & 72 & 10.3 \\
\hline 6 & Czech Republic & 6 & 51 & 8.5 \\
\hline 7 & Austria & 5 & 6 & 1.2 \\
\hline 8 & Canada & 5 & 12 & 2.4 \\
\hline 9 & Italy & 5 & 21 & 4.2 \\
\hline
\end{tabular}




\begin{tabular}{|c|c|c|c|c|}
\hline 10 & Taiwan & 5 & 64 & 12.8 \\
\hline 11 & Malaysia & 4 & 5 & 1.3 \\
\hline 12 & Finland & 3 & 6 & 2.0 \\
\hline 13 & Germany & 3 & 4 & 1.3 \\
\hline 14 & Croatia & 2 & 3 & 1.5 \\
\hline 15 & India & 2 & 7 & 3.5 \\
\hline 16 & Iran & 2 & 0 & 0.0 \\
\hline 17 & New Zealand & 2 & 4 & 2.0 \\
\hline 18 & Sweden & 2 & 2 & 1.0 \\
\hline 19 & Belgium & 1 & 0 & 0.0 \\
\hline 20 & Chile & 1 & 0 & 0.0 \\
\hline
\end{tabular}

Table 3. Top 20 countries

Figure 4 shows the institutions affiliated with the analyzed publication. It is demonstrated that there is no central institution that focuses on this type of research since most of the research was done by various institutions all over the world. This has thus emphasized the importance of specialized academic centers in the field of emerging technologies in accounting.

\section{COMPLUTENSE UNIVERSITY OF MADRID}

THE UNIVERSITY OF THE SUNSHINE.

UNIVERSITY OF DEUSTO

KENT STATE UNIVERSITY

BRIGHAM YOUNG UNIVERSITY

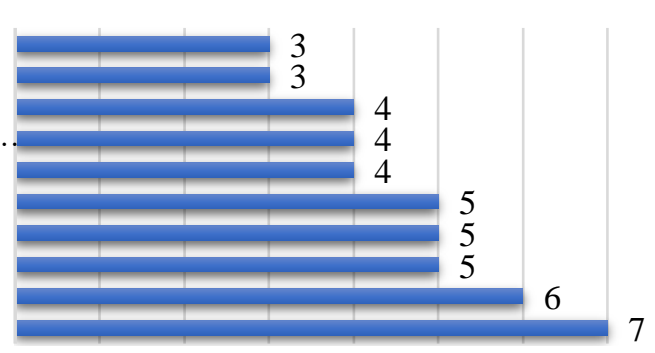

$\begin{array}{lllllllll}0 & 1 & 2 & 3 & 4 & 5 & 6 & 7 & 8\end{array}$

Figure 4. Most relevant institutions

Table 4 shows the top and most relevant journals associated with the topic. Journal of Emerging Technologies in Accounting leads this research area in terms of the 
number of publications, achieving $7.8 \%$ of the total published documents. In the second position, three journals have the same publication volume, International Journal of Accounting Information Systems, Journal of Information Systems, and Managerial Auditing Journal.

Obviously, the research in this area has not received the required attention since the world is witnessing a revolution concerning the new emerging technologies that are constantly changing everyday life as well as business operation nature.

\begin{tabular}{|c|c|c|c|}
\hline Number & Source & Documents & Citations \\
\hline 1 & Journal Of Emerging Technologies In Accounting & 12 & 58 \\
\hline 2 & $\begin{array}{l}\text { International Journal Of Accounting Information } \\
\text { Systems }\end{array}$ & 5 & 93 \\
\hline 3 & Journal Of Information Systems & 5 & 40 \\
\hline 4 & Managerial Auditing Journal & 5 & 139 \\
\hline 5 & International Journal Of Digital Accounting Research & 4 & 20 \\
\hline 6 & $\begin{array}{l}\text { New Review Of Applied Expert Systems \& Emerging } \\
\text { Technologies }\end{array}$ & 4 & 0 \\
\hline 7 & Accounting And Business Research & 3 & 55 \\
\hline 8 & Australian Accounting Review & 3 & 19 \\
\hline 9 & Decision Sciences & 3 & 156 \\
\hline 10 & decision support systems & 3 & 22 \\
\hline
\end{tabular}

Table 4. Most relevant sources

Figure 5 shows the most productive authors. Miklos Vasarhelyi is the top contributor from Rutgers University (USA). He has published some pioneering articles, one of which is "big data and analytics in the modern audit engagement: Research needs". Deniz Appelbaum is the second top contributor from Montclair State University and James V. Hansen from Brigham Young University. 


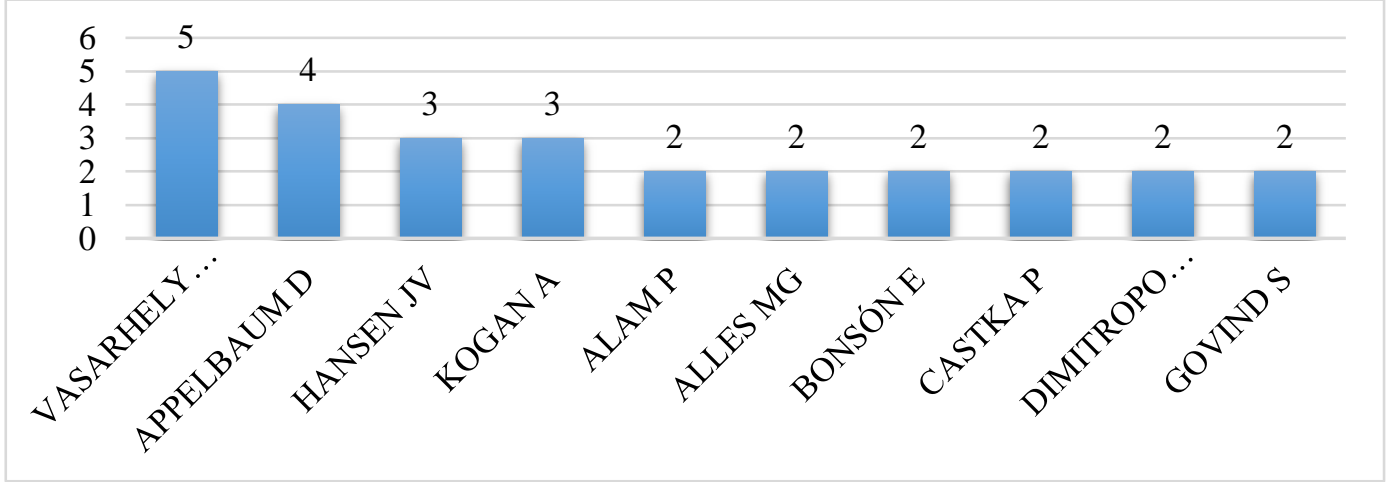

Figure 5. Most relevant authors

Figure 6 presents the volume and diversity of countries and journals contributions to the field. The left column presents the nature of countries contribution; the USA is the top diversified contributor to various technological aspects in auditing and tax (presented in the middle column), followed by China and the UK. At the same time, the journal of emerging technologies is the most diversified contributor, followed by the accounting horizon.

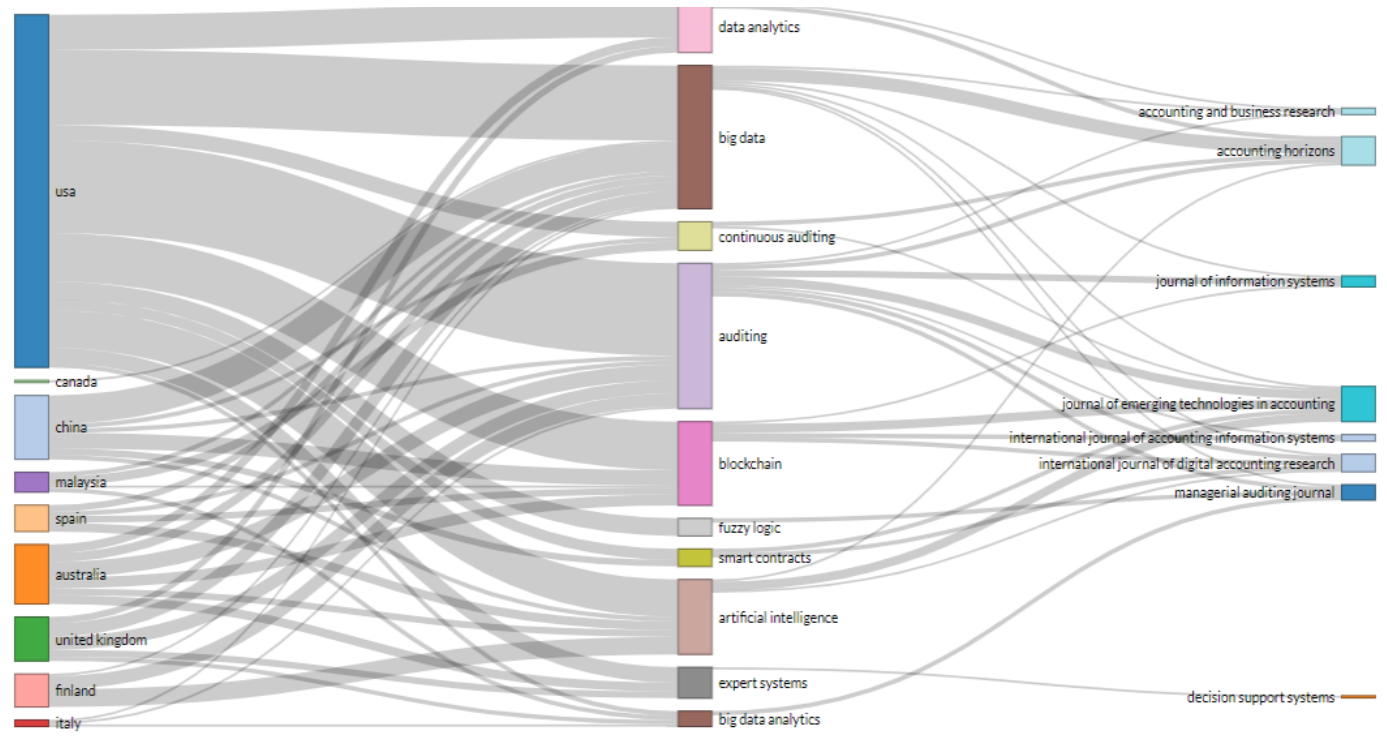

Figure 6. Three fields plot

\subsection{Citation analysis}

Citation signifies the impact of research (Seglen, 1989). Citation analysis states the connection between two documents. Despite the citation as an influential measurement tool, it has been criticized for misrepresenting papers' quality. 
Nevertheless, it is still the best way to measure certain scientific actors' influence in the scientific field. Figure (7) shows the citation pattern during the past 37 years. The total number of citations is 1,701, while the citations' growth was in the last five years, with a percentage of $(61 \%)$. This study expects that the topic may get more attention in the near future; this appears from the citation growth and the publication volume, as presented in figure 2 .

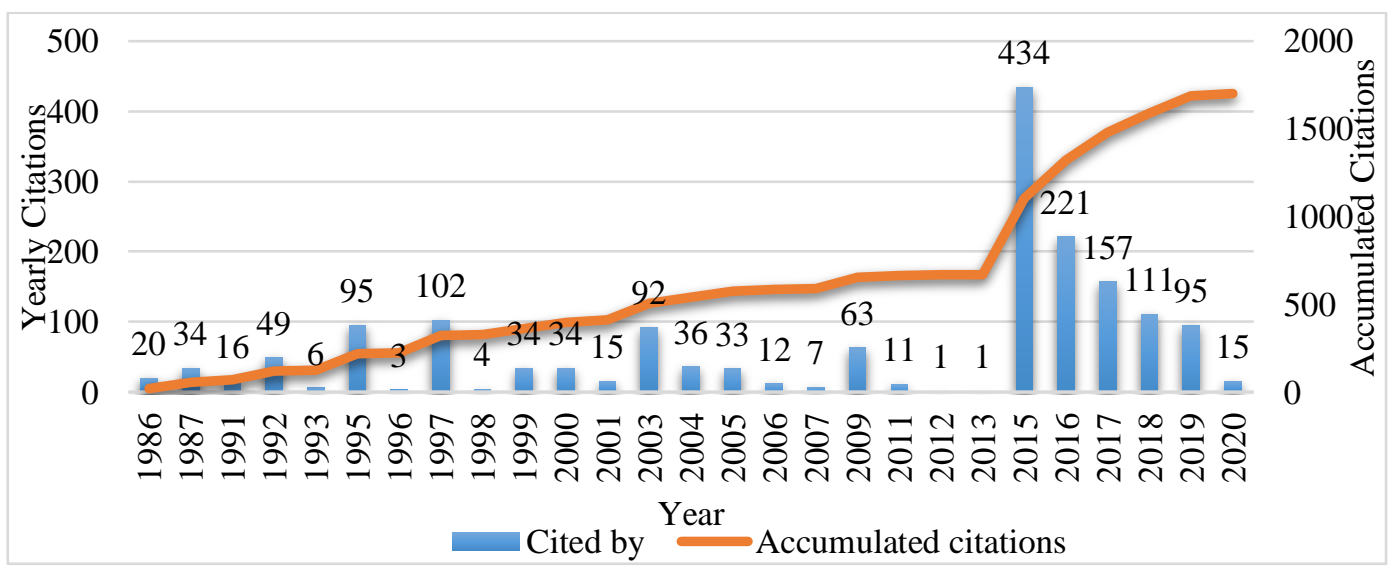

Figure 7. Citation pattern

This section presents the most cited documents in the table 5. West and Bhattacharya (2016), coming in the top position among other contributors, conducted a comprehensive review of intelligent financial fraud detection. West and Bhattacharya reviewed more than fifty documents from 2004 to 2014. The authors used data mining methods to analyze the selected research articles concerning financial fraud detection. In the second position comes Lin et al. (2003), who conducted a paper to evaluate the utility of integrated fuzzy neural network (FNN) for fraud detection. In the third position, Lenard et al. (1995) stated that the neural network model enhances the auditor's prediction accuracy and assessing the clients' going concern, especially in uncertain circumstances. The most outstanding three articles discussed the financial reports fraud and auditing issues.

\begin{tabular}{|l|l|c|c|c|}
\hline \multicolumn{1}{|c|}{ Authors } & \multicolumn{1}{|c|}{ Title } & Year & Source title & Citation \\
\hline $\begin{array}{l}\text { (West \& } \\
\text { Bhattacharya, } \\
\text { 2016) }\end{array}$ & $\begin{array}{l}\text { Intelligent financial fraud detection: A } \\
\text { comprehensive review }\end{array}$ & 2016 & $\begin{array}{l}\text { Computers and } \\
\text { Security }\end{array}$ & 98 \\
\hline
\end{tabular}


(Lin et al., A fuzzy neural network for assessing 2003) the risk of fraudulent financia reporting

The Application of Neural Networks (Lenard et al., and a Qualitative Response Model to 1995) the Auditor's Going Concern Uncertainty Decision
Managerial Auditing Journal

92

1995 Decision Sciences

90

(Eining, Jones, Reliance on decision aids: An \& Loebbecke, examination of auditors' assessment of 1997) management fraud

1997

Auditing

(La Torre,

Botes, Dumay, Behavioural implications of big data's

Rea, \& impact on audit judgment and decision

2015

Accounting Horizons

Odendaal, making and future research directions 2018)

(Cao,

Chychyla, \&

Big data analytics in financial statement audits

2015 Accounting Horizons

Stewart, 2015)

(Bonsón, Towards the global adoption of XBRL

Cortijo, \& using International Financial Reporting

2009

Int. Journal of

Accounting

Escobar, 2009) Standards (IFRS)

Information Systems

(Yoon,

Hoogduin, \&

Zhang, 2015)

Big data as complementary audit evidence

2015 Accounting Horizons

(Krahel \&

Titera, 2015)

Consequences of big data and formalization on accounting and 2015

Accounting Horizons auditing standards

Drivers of the use and facilitators \&

(Alles, 2015) obstacles of the evolution of big data by the audit profession

2015 Accounting Horizons

(Zhang, Yang, \& Appelbaum, 2015)

Toward effective big data analysis in continuous auditing

(Hansen, McDonald, \& Stice, 1992)

Artificial Intelligence and Generalized Qualitative? Response Models: An Empirical Test on Two Audit 


\begin{tabular}{|c|c|c|c|}
\hline $\begin{array}{l}\text { (Hajek \& } \\
\text { Henriques, } \\
\text { 2017) }\end{array}$ & $\begin{array}{l}\text { Mining corporate annual reports for } \\
\text { intelligent detection of financial } \\
\text { statement fraud - A comparative study } \\
\text { of machine learning methods }\end{array}$ & 2017 & $\begin{array}{c}\text { Knowledge-Based } \\
\text { Systems }\end{array}$ \\
\hline
\end{tabular}

(Appelbaum, Kogan, \& Vasarhelyi, 2017)

(Gepp, Linnenluecke, O'Neill, \& Smith, 2018)
Big data and analytics in the modern audit engagement: Research needs
Big data techniques in auditing research and practice: Current trends and future opportunities
2018 Journal of Accounting

Literature
2017

Auditing

Table 5. Most Cited Documents

Figure 8 presents the most cited authors. The top contributor is Miklos Vasarhelyi from Rutgers University (USA). He is the top influential author in audit and tax research in the emerging technology context. The top ten cited authors have harvested $22 \%$ of the total number of citations in the field. Thereby, these authors are the benchmark in this field.

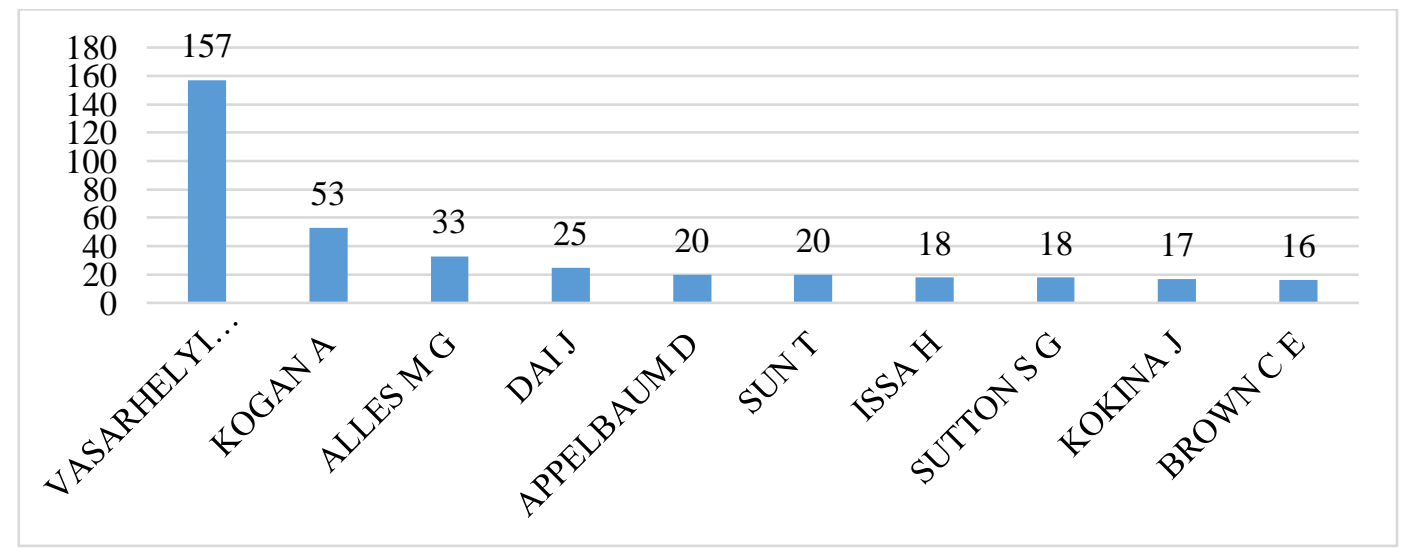

Figure 8. Most Cited Authors

Table 6 shows the most cited sources in this field, out of 89 sources. The study used the VOSviewer to generate the list below, which presents the most cited sources in the latter scientific domains. The table illustrates that the Decision Sciences Journal followed by the Managerial Auditing Journal and Auditing Journal are the most cited in the extant literature. These top ten cited journals had been the source of $53 \%$ of the total harvested citations. 


\begin{tabular}{|c|l|c|}
\hline No. & \multicolumn{1}{|c|}{ Sources } & Freq \\
\hline 1 & Decision Sciences & 156 \\
\hline 2 & Managerial Auditing Journal & 139 \\
\hline 3 & Auditing & 125 \\
\hline 4 & Computers and Security & 98 \\
\hline 5 & International Journal of Accounting Information Systems & 93 \\
\hline 6 & Accounting Horizons & 81 \\
\hline 7 & Journal of Emerging Technologies in Accounting & 58 \\
\hline 8 & Accounting and Business Research & 55 \\
\hline 9 & Intelligent Systems in Accounting, Finance and Management & 52 \\
\hline 10 & Knowledge-Based Systems & \\
\hline
\end{tabular}

Table 6. Most Cited Sources

\subsection{Network analysis}

This section analyses the dataset using VOSviewer. The study mainly applies three types of analysis: 1 . keywords/cartography 2 . field development over time, and 3. topics trend.

\subsubsection{Keywords/cartography analysis}

This test reaffirms our choice of selection as it represents the most frequent keywords in the collected dataset. This section is in line with the authors' keywords. We determined the occurrence threshold at two levels, revealing 53 keywords. Out of 398 total words, figure 9 shows the main themes in the literature. This analysis illustrates the high connectedness of terminologies with their suitable applications, for instance, blockchain with smart contracts and industry 4.0 as well as blockchain with audit and internal audit. Big data is connected with decision making, expert systems, and analytics. Likewise, artificial intelligence is connected with big data, decision support systems, tax evasion, and automation. Auditing is linked with 
neural networks and expert systems. This analysis strengthens and supports the qualitative findings and keywords selection strategy of this study.

Auditing is almost connected to all technological terminologies. From the tax perspective, big data is connected with value-added tax and tax evasion. This study, however, finds that the blockchain is linked with tax compliance, while artificial intelligence is indirectly connected with tax administration. The figure 9 below provides more elaboration about the connectedness and development of the critical keywords employed in the literature.

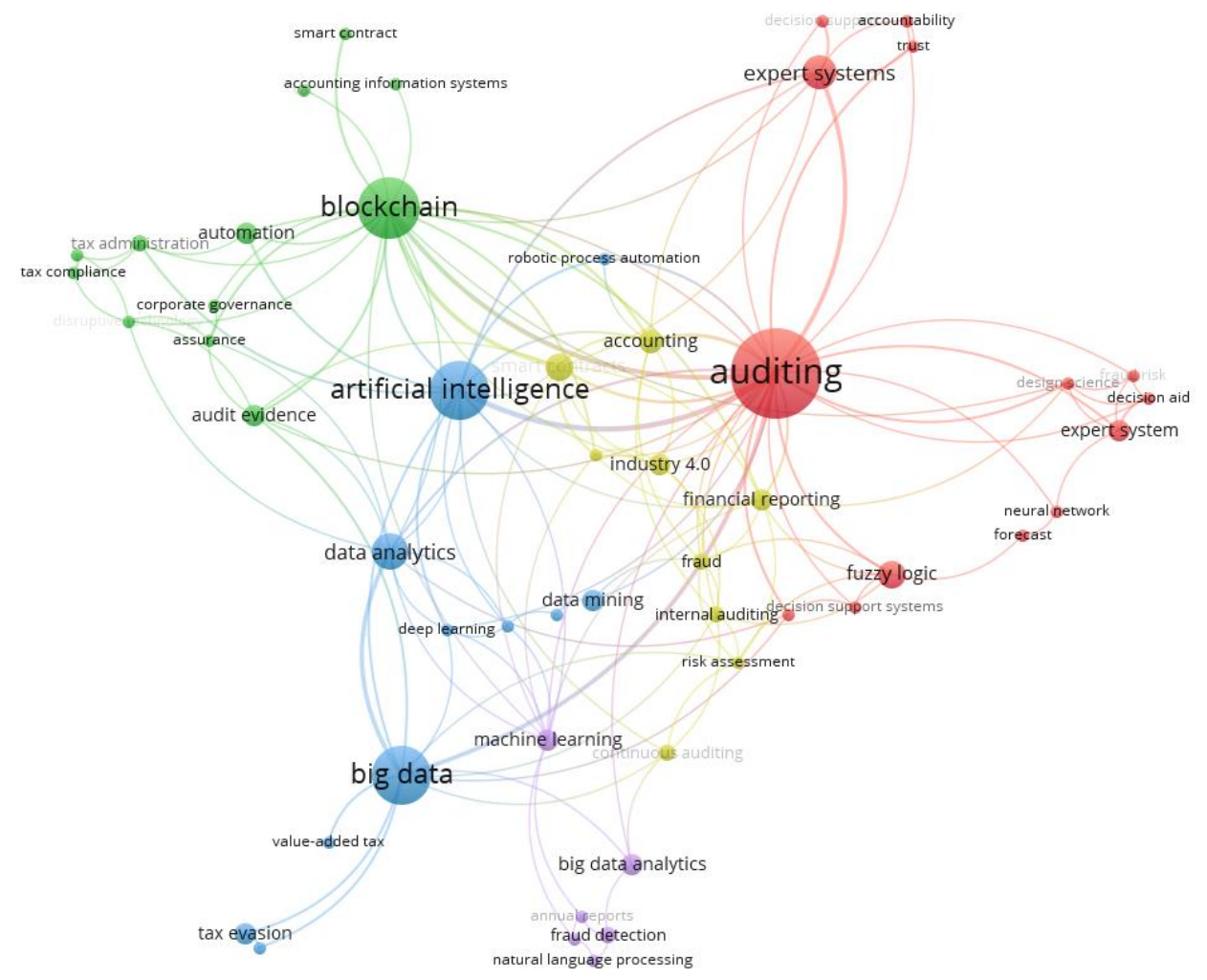

Figure 9. Keyword analysis/cartography

Figure 10 demonstrates the development of key concepts over the last ten years in the literature. The figure illustrates that the darker links and nodes witnessed older discussed, while the lighter nodes and links are the more recent topic has discussed. From a technology perspective, both the expert systems and decision support system have been early discussed. Recently, the scientific community have focused more on trending topics (i.e., artificial intelligence and big data) and the blockchain area. From an accounting perspective, auditing is the old-new topic. 


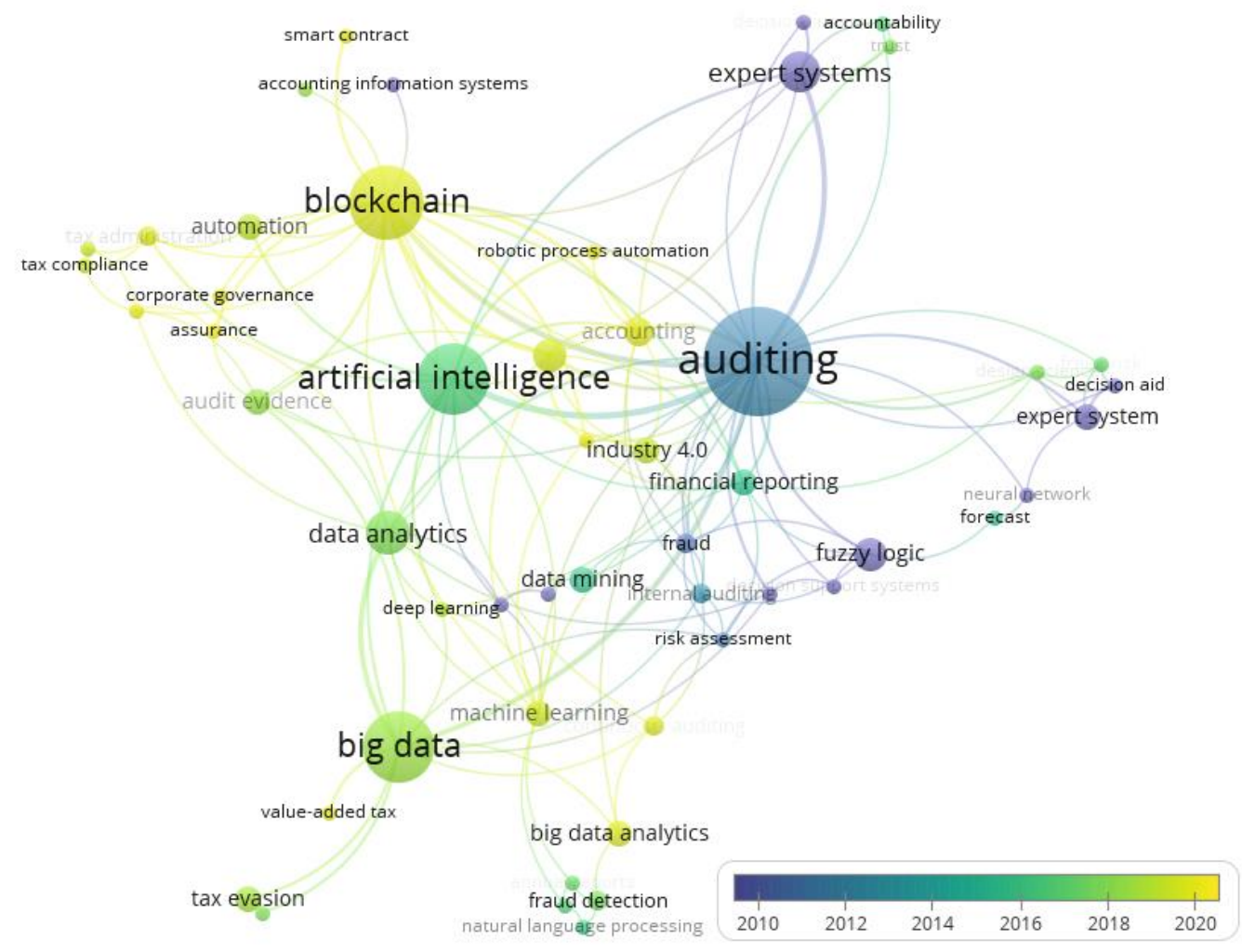

Figure 10. Field development over (10 years)

\subsubsection{Topic trend}

Figure 11 shows the trending topics over the last 30 years, which helps figure out this field's evolving structure. The figure shows that the most significant changes in the audit and tax field's intellectual structure occurred during the last ten years. Over these years, discussions have been raised concerning big data, artificial intelligence, and blockchain applications, opportunities, and challenges encountered in the audit and tax. The figure shows that fuzzy logic and expert systems technological topics face decline or stable trends. 


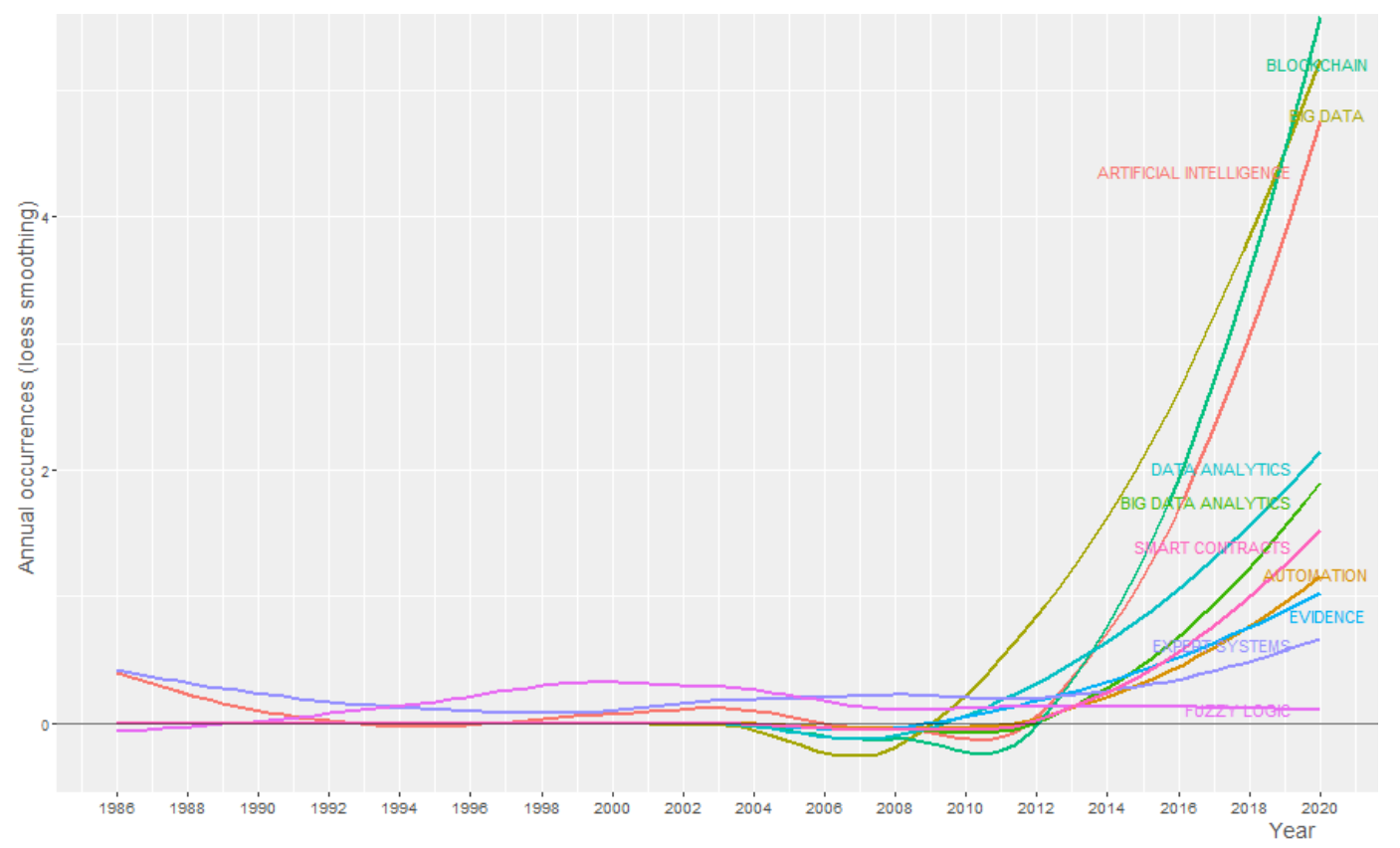

Figure 11. Topics trend

\subsection{Content analysis}

This part of the study discusses the extant academic literature in auditing and tax in the context of emerging technologies. Serving this study aims, content analysis has been carried out for the relevant studies. The above analysis reveals two mainstreams: 1- the emerging technologies in auditing and assurance, and 2- the emerging technologies in tax. Each mainstream was classified into three substreams, namely, big data, artificial intelligence, and blockchain.

\subsubsection{Emerging technologies in auditing and assurance}

The ramification of emerging technologies on the audit industry was addressed in 120 studies classified into three sub-streams, big data, blockchain, and AI. Recently, technological advancements have crucially changed the nature of auditing procedures and the auditors' required competencies. The audit practitioners should be equipped with technological skills to enhance the auditing efficiency and effectiveness in terms of cost, time, and added value to clients. This helps them assess accurately and reliably.

The first sub-stream studied big data use in the auditing industry. This sub-stream consists of 31 studies. The various forms of massive data present a challenge to the 
practitioner's work (Feung \& Thiruchelvam, 2020). Analyzing a large amount of big data offers an opportunity to enhance the practitioner's ability to reach more accurate judgment (Kend \& Nguyen, 2020). However, the current emerging technologies present a challenge for professional audit bodies to harmonize the current auditing standards in the audit industry's current changes (Shukla \& Mattar, 2019).

Many studies documented the benefit of using a combination of structured and unstructured data in audit evidence (Janvrin \& Weidenmier Watson, 2017; Astami et al., 2017). Tang and Karim (2019) found that an auditor's use of unstructured data is still limited and thus recommended upgrading the practitioners' skills to manage the data variety, velocity, volume, veracity, and value. Because the benefits of big data use in the auditing process could vary based on the precise time used, the use of big data interpretation, as having been documented, provides better advantages if used after evaluating the traditional audit evidence (Rose et al., 2017). Accordingly, many studies identified a gap between the accounting curricula and the auditing firms' needed skills. Zhang (2018) pointed out the necessity to optimize and update the accounting curricula with advanced technologies to meet the market needs and equip the accounting graduates with relevant and suitable competencies. Thus, this study recommends that the academic curricula integrate with the recent software skills such as Qlik Sense, IBM Cloud Pak for Data, and Azure Databricks.

There are 68 studies that have so far discussed the sub-stream about AI in the auditing field. At the initial stages in the 1980s, the expert systems and decision support systems were among the first genuinely successful AI forms. Many studies documented both systems' usefulness in enhancing and offering support to the auditors' judgments (Rushinek \& Rushinek, 1986; Wensley, 1986; Connell, 1987). Elliott (1986) raised the issue of audit education and thus recommended that the accounting students be equipped with the technological skills to utilize the auditing technologies in the 1990s. This could be accomplished by optimizing the accounting curricula and investing more in research projects to identify the gap between the academic output and the industry input. Later in the 1990s, 13 studies investigated AI. Jacob \& Bailey (1991) stated that expert systems' use is limited and valuable only in specific audit decisions. Hence, there is a need for establishing a network of expert processors, each of whom could apply for a particular decision, rather than using multiple expert systems. In other words, integrating multiple 
expert systems could enhance their efficiency and utilization to cover broader auditing decisions. Other studies recommended using machine-learning (ML) (qualitative-response model) in auditing decisions and judgment. ML provides a potential for significant improvement to the audit time and quality since it could help the auditor build more accurate and timely decisions and judgments (Hansen et al., 1992).

Later, Lenard et al. (1995) documented the effectiveness of the Generalized Reduced Gradient (GRG2) system (based on neural network technology) in supporting the auditors' assessment of their clients' going concern position. By the end of the 1990s, it was reported that expert systems and neural networks were found to be better than experienced auditors in finding the relationship between a large number of variables to support the process of auditor risk assessment (Cerullo \& Cerullo, 1999; Friedlob \& Schleifer, 1999; Buckless et al., 2000). Eining et al. (1997) carried out an experiment to examine the auditors' reliance on the expert systems in determining the fraud risk. The results revealed that auditors ignored the use of expert systems, even in foggy cases and complex decisions. The aforementioned discussion emphasizes the importance of technology acceptance, trust, and skills. Many studies documented the limited use of expert systems in uncertain situations in the 1990s. In the 2000s, the AI used by auditors expanded; this is due to the increase in the trust and auditors to use the technologies to accomplish work activities. The AI expands the scope of CPA firms' services (Manita et al., 2020) improves auditor decision making and judgment (Zhang, 2019), leverages auditors' ability to expect the clients' going concern (MuñozIzquierdo et al., 2019), and helps auditors to reach reliable and accurate opinion (Cičak \& Vašiček, 2019; Goryachikh et al., 2019; Sun, 2019).

The third sub-stream discussed the use of blockchain in auditing. There were only 21 studies published in the use of blockchain in auditing between 2019 and 2020. Bonsón and Bednárová, (2019) stated that the implication of blockchain in accounting is still unclear, as it faces challenges of instability and as the technology is still in its early development phase. Due to its broad application and benefits, blockchain in accounting is still witnessing continuous improvement; thus, it is difficult to integrate the blockchain into the current accounting practices. Besides, security matters are of great concerns. Blockchain has already received a significantly growing body of specialized research in both academia and industry. 
This explores the possible opportunities brought to the audit and assurance field (Mohamad et al., 2020). Researchers have investigated the benefits of applying blockchain technology in auditing, including improve the auditors' ability in realtime transaction capturing, enhance the clients' data transparency and data reliability, and develop the ability of the auditor to obtain timelier and more relevant audit evidence (Bonyuet, 2020; Rozario \& Thomas, 2019; Smith \& Castonguay, 2020; Wang et al., 2020).

Generally, there were 120 studies conducted to measure and explore the audit in the digital era. These studies have documented that advanced technologies are applicable and could be used in the audit field, as these technologies enhance the accuracy, reliability, and audit timing. Unlike auditors in the era of the 1990s, auditors of the present day are more familiar and open to use technological advancements in their work. Despite that accounting, scholars need to conduct indepth studies to optimize and develop the accounting curricula to meet the market expectations and needs. The labour market has recently preferred professional rather than academic certificates; since professional certificates fulfil the market needs faster than higher institutions. Hence, academicians should be more efficient and flexible to customize their programs to equip students with adequate and relevant competencies relevant to the market.

\subsubsection{Emerging technologies and taxation}

The rapid expansion of emerging technologies used in modern markets has significantly influenced the tax field. 34 studies have discussed the impact of big data, blockchain, and artificial intelligence on tax. The common concern in the literature revolves around the use of advanced technologies in tax administration. This includes the filing, audit, and detection of non-compliance cases.

The first sub-stream of the literature discussed, in ten studies, the impact and use of big data on tax evasion. The advent of big data has brought challenges and opportunities to the tax system worldwide (Wang, 2017). Currently, online trading presents relevant data sources to the policymakers to track the final consumption trend, enhance tax authorities' ability to supervise the market, and obtain feedback about the current tax policies' effectiveness (Gao et al., 2020). Other researchers documented that social media has increased tax evasion to enable taxpayers to increase their consumption budgets and boost their high lifestyle to their relatives on social networks (Gamannossi \& Rablen, 2020). Tax authorities have 
increasingly used massive data analysis to detect any potential non-compliance cases or tax evasion matters.

Consequently, the Internal Revenue Service (IRS) started utilizing big data from online platforms and social media to determine taxpayers' non-compliance with the tax rules and regulations (Houser \& Sanders, 2018). Consistently, Politou et al., 2019) confirmed that European countries' tax authorities employed big data and machine learning in the tax conformance checks. The use of taxpayers' private data to evaluate the compliance degree raised the issue of harmonizing the tax rules and regulations about protecting taxpayers' data privacy. Interestingly, mitigating human discrimination risk is one of the astonishing benefits out of the use of automated taxpayer conformance. The use of machines does not discriminate between the taxpayers based on race, sex, color, religion, and political connections.

Big data technology has led to the development of applicable artificial intelligence (AI) and Machine Learning (ML) technology to handle massive data. Thus, the second substream discussed AI in the field of tax in 16 articles. The researchers started in 1992 to examine the fuzzy logic efficiency in discovering suspicious tax transactions. Shnaider \& Kandel (1992) documented the efficiency of fuzzy technology in predicting business income tax. This offers a base to identify noncompliance by comparing the actual tax filed with fuzzy logic predictions. Best \& Teske (2007) explored the impact of internet sales on tax collection and policy harmonization in the United States of America. Having used a 50-state comparison, the authors recommended using emerging technologies in tax collection, audit, and monitoring. Furthermore, Ruan et al., (2019) stated that the complex and voluminous transactions offer a chance for the business to manipulate their taxes. Hence, many technologies were developed to enhance the effectiveness of tax authorities' work. Some of these technologies are the Taxpayer Interest Interacted Network (TPIIN) (Tian et al., 2016), 3TI method (Ruan et al. 2019), TAXNET technology (Didimo et al., 2018), and automatic online risk analysis (Sobotka \& Vrana, 2007). These technologies were found robust tools to detect suspicious transactions and tax avoidance on both levels of business and individuals. The aforementioned development raised the unemployment issue in the AI and ML era. Several studies have provided evidence on the importance of imposing an extra tax on organizations using AI and ML in their operation. This initiative aims to finance any practical solution to the increasing unemployment rates that have resulted from 
the use of robots and automation in business operations (Gasteiger \& Prettner, 2020; Ionescu, 2019; Zhang, 2019).

The third sub-stream discussed the use of blockchain technology in tax. The utilization of blockchain technology in digital currencies motivates the researchers to investigate its potential use in the accounting field (Coyne \& McMickle, 2017). This substream includes only five studies describing the effect of blockchain technology on tax. These studies utilized the blockchain in controlling and monitoring the Value Added Tax (VAT). These studies found that blockchain technology enhances VAT records' transparency and improves the VAT collection mechanism (Alkhodre et al., 2019; Bentley, 2019; Kollmann, 2019). Merkx (2019) stated that blockchain technology, which is still in the improvement stage, might face some challenges in tax uses, such as identifying the reverse charge mechanisms. The blockchain shortcomings can be avoided if better governance for the tax process is implemented.

\subsection{Future research questions}

Emerging technologies have boosted the stakeholders' interests since rapid technological advancement is remodeling the accounting profession's nature (Ahmad, 2019). These transformations foster the necessity to explore this knowledge field and offer a comprehensive perception. The previous content analysis helped the researchers to identify the research gaps and develop a road map for future research proposals.

In the audit stream, the first sub-stream is the big data where the literature gap is generally related to 1 - the implications of big data on the auditing - process efficiency, 2- needed auditor skills, 3- optimization of the auditing standards, and 4- the expected variation in the audit profession efficiency between countries in terms of the opportunities and challenges facing the big data utilization in the audit. The second sub-stream discusses the use of AI in the audit profession. Six questions are identified.

The main concern is whether and how the AI use adds value to the auditing firms and their clients. The main concern is how AI enhances the auditor's work accuracy and the auditor's ability to deal with various audit evidence concerning quality and quantity. The concern also includes the auditors' ability to evaluate the auditors' evidence to reach a reliable conclusion about how accurate the clients' financial 
reports are. The last sub-stream identified future research opportunities about the use of blockchain in the audit profession. The five identified literature gaps concerned blockchain governance and how it helps in overriding the government bureaucracy. The five identified literature gaps identified the applicable internal control and how it could affect the auditors' ability to assess the internal controls.

The study identified 13 gaps in the second mainstream exploring the relevant technologies (Big data, AI, and blockchain). The big data use in tax mainly focuses on utilizing it in conforming with the tax rules and regulations. There are no studies that have not yet explored how big data mitigates the risk of data quality and how big data impacts the taxpayers' behaviors on social media. Furthermore, no studies have yet investigated social media's role as one of the primary big data sources in developing countries that can utilize big data in their tax authority operations. The second sub-stream focused on AI utilized in the tax administration, mainly using AI on the tax agents' work stability. The second sub-stream also sheds light on the tax agents' opportunities to employ IT companies to develop tax AI technologies. In fact, no studies have yet explored the AI's utilization in the courts to resolve tax disputes, nor have there yet studies investigated the challenges and opportunities in using virtual tax agents. The last research opportunities discussed blockchain technologies in the tax field. The literature's focal point was how the blockchain would contribute towards more tax compliance, how the current tax regulations should be optimized to fit the use of blockchain in tax administration and operation, and what the challenges to be faced. The study also tries to investigate how the blockchain accurately identifies the different types of income. More critical and detailed questions have been presented in table 7 .

\begin{tabular}{|c|c|c|c|}
\hline Mainstream & Sub-stream & Research Questions & Source \\
\hline \multirow{4}{*}{$\begin{array}{l}\text { Auditing } \\
\text { and } \\
\text { Assurance }\end{array}$} & \multirow{4}{*}{ Big data } & $\begin{array}{l}\text { 1. How big data changes the nature, } \\
\text { scope, and timing of auditor } \\
\text { work? }\end{array}$ & Authors \\
\hline & & $\begin{array}{l}\text { 2. Does big data affect the audit cost, } \\
\text { and how? }\end{array}$ & $\begin{array}{c}\text { (Moll \& Yigitbasioglu, } \\
\text { 2019) }\end{array}$ \\
\hline & & $\begin{array}{l}\text { 3. What is the current gap of } \\
\text { auditors' competencies? And how } \\
\text { could it be filled? }\end{array}$ & Authors \\
\hline & & $\begin{array}{l}\text { 4. Are the current auditing standards } \\
\text { applicable to the big data era? }\end{array}$ & Authors \\
\hline
\end{tabular}




\begin{tabular}{|c|c|c|c|}
\hline & & $\begin{array}{l}\text { 5. What are the challenges and } \\
\text { opportunities facing the use of big } \\
\text { data in the audit profession? }\end{array}$ & Authors \\
\hline & \multirow{6}{*}{$\begin{array}{c}\text { Artificial } \\
\text { Intelligence }\end{array}$} & $\begin{array}{l}\text { 1. Does the use of AI and ML affect } \\
\text { the perception of stakeholders to } \\
\text { the audit profession? }\end{array}$ & Authors \\
\hline & & $\begin{array}{l}\text { 2. How does the use of AI enhance } \\
\text { the accuracy of auditors' } \\
\text { conclusions and risk assessment? }\end{array}$ & $\begin{array}{c}\text { (Joshi \& Marthandan, } \\
\text { 2020) }\end{array}$ \\
\hline & & $\begin{array}{l}\text { 3. Does the use of AI enable the } \\
\text { auditors to examine and } \\
\text { investigate the full population } \\
\text { rather than using a sample? }\end{array}$ & Authors \\
\hline & & $\begin{array}{l}\text { 4. Does the use of AI expand the } \\
\text { auditors' evidence variety? }\end{array}$ & Authors \\
\hline & & $\begin{array}{l}\text { 5. In the case of generalizing the use } \\
\text { of AI, how could this expand the } \\
\text { gap of service quality between the } \\
\text { big four and other CPA firms? }\end{array}$ & Authors \\
\hline & & $\begin{array}{l}\text { 6. Does the use of AI add more value } \\
\text { to the clients of CPA firms? }\end{array}$ & Authors \\
\hline & \multirow{5}{*}{ Blockchain } & $\begin{array}{l}\text { 1. How could blockchain technology } \\
\text { help to override the government } \\
\text { bureaucracy? }\end{array}$ & Authors \\
\hline & & $\begin{array}{l}\text { 2. What are the necessary changes in } \\
\text { audit standards in the blockchain } \\
\text { era? }\end{array}$ & Authors \\
\hline & & $\begin{array}{l}\text { 3. Does the use of blockchain in } \\
\text { client operations affect the } \\
\text { auditor's assessment of internal } \\
\text { control? }\end{array}$ & Authors \\
\hline & & $\begin{array}{l}\text { 4. How could the use of blockchain } \\
\text { affect the governance } \\
\text { mechanism? }\end{array}$ & Authors \\
\hline & & $\begin{array}{l}\text { 5. Does the use of blockchain } \\
\text { increase the auditor's work } \\
\text { efficiency? }\end{array}$ & $\begin{array}{c}\text { (Moll \& Yigitbasioglu, } \\
\text { 2019) }\end{array}$ \\
\hline \multirow{4}{*}{ Tax } & \multirow{3}{*}{ Big data } & $\begin{array}{l}\text { 1. Does the large quantity of tax data } \\
\text { compensate for its quality? }\end{array}$ & $\begin{array}{l}\text { (Appelbaum, et } \\
\text { al.,2017) }\end{array}$ \\
\hline & & $\begin{array}{l}\text { 2. Does the use of big data enhance } \\
\text { the compliance of taxpayers? }\end{array}$ & Authors \\
\hline & & $\begin{array}{l}\text { 3. What are the challenges of using } \\
\text { big data in developing countries? }\end{array}$ & Authors \\
\hline & & $\begin{array}{l}\text { 1. What is the role of AI in } \\
\text { developing a virtual tax advisor? }\end{array}$ & Authors \\
\hline
\end{tabular}




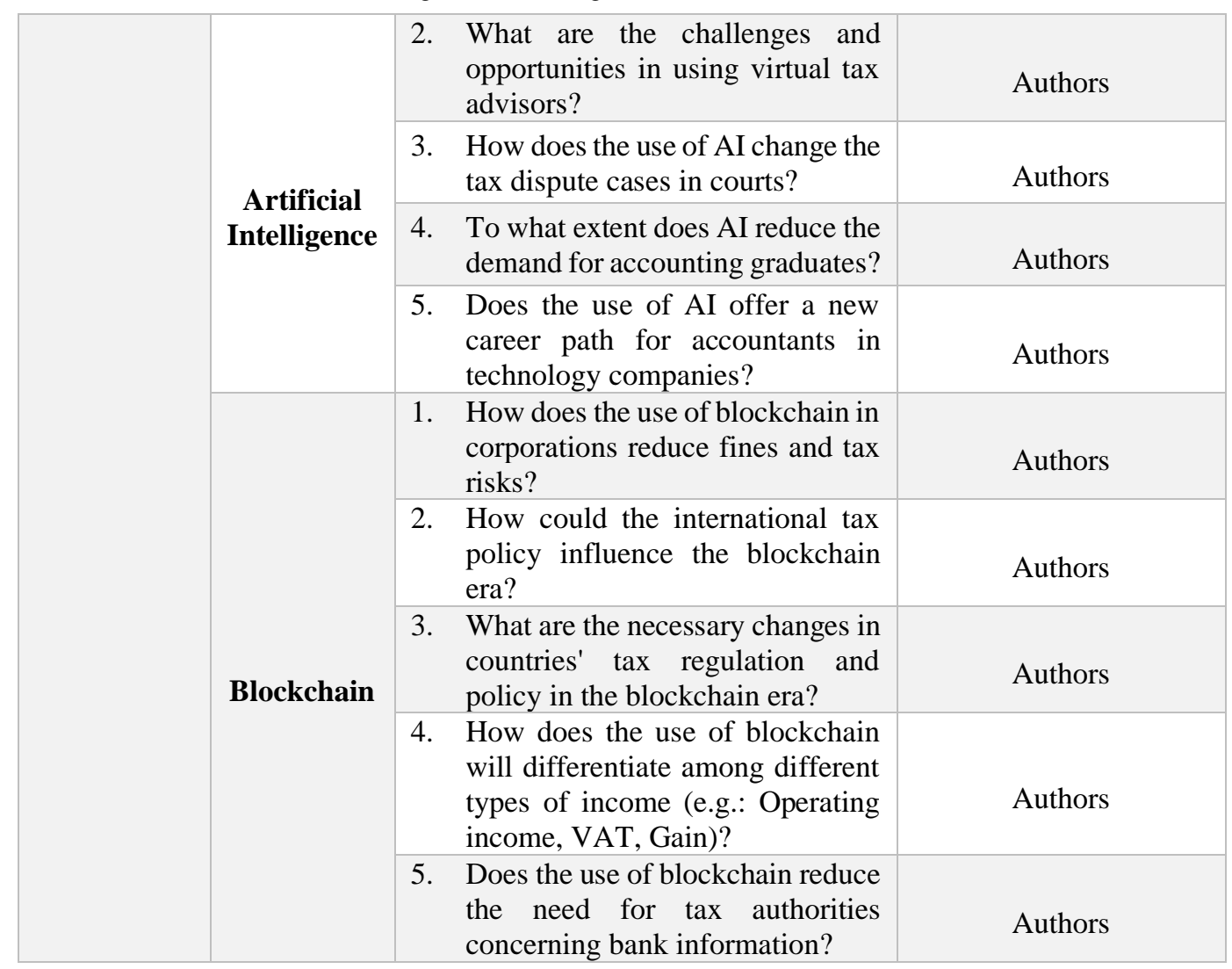

Table 7. Future Research Questions

\section{CONCLUSIONS}

To improve the conceptual framework of new technology in audit and tax literature, we performed a two-tier study that included bibliometric and content analyses. Bibliometric analysis is a common research tool that analyzes the current literature and offers insights for future development. This study has explored and examined the most influential articles, authors, institutions, and countries in the field of advanced technologies in audit and tax. The study has reviewed the existing literature and demonstrates 154 relevant articles and reviews associated with 89 journals, concerning the emerging technologies in audit and tax. Most of the papers (75.3\%) were published from 2015 and thereafter. The most contributing countries are the USA, Australia, and China, respectively. The most productive institution is Brigham Young University, followed by Hanken School of Economics. The most relevant source is the Journal of Emerging Technologies in Accounting, International Journal of Accounting Information Systems, and the Journal of Information Systems. The most cited was Decision Sciences, Managerial Auditing 
Journal, and Journal of Auditing. The most cited papers are "Intelligent financial fraud detection: A comprehensive review" by West and Bhattacharya, followed by "A fuzzy neural network for assessing the risk of fraudulent financial reporting" by Lin, Hwang, and Becker. While the most cited authors are Vasarhelyi, M.A., and Appelbaum, D.

The conducted content analysis illustrates that the audit profession has benefited from emerging technologies in many areas. For instance, it enhances the audit efficiency and reliability, reduces the audit time and cost, develops the decisionmaking process, and collects real-time evidence. At the same time, this study suggests that auditors must be equipped with appropriate technical skills and tools to efficiently use the technologies, interpret structured and unstructured data, and visualize the financial information. In the tax field, governments usually pay special efforts to secure their vital revenue source, especially the tax. The use of advanced technologies offers promising opportunities to mitigate the risk of tax evasion and enhance tax authorities' abilities to detect suspicious transactions and noncompliance cases. This may help in reducing the burden on societies by empowering for less tax imposition. This study shows that the use of big data, AI, and blockchain in tax and auditing, should comply with ethical aspects, such as but not limited to taxpayer data privacy and protection, technologies governance.

The advanced technologies in accounting could be affected by the higher education institution output since these technologies reshape the accounting profession. This leads to higher education playing a vital role in equipping students with the needed skills in the up-to-date market by optimizing the accounting curricula and carrying out more research on the topic.

This study has accurately described past and current intellectual contributions in audit and tax and emerging technologies, besides developing a road map for further contributions. The study recommends that more studies should be conducted to explore, assess, and investigate the existing literature in other accounting fields (Managerial accounting, cost accounting, financial accounting, education, and accounting profession) in the context of industry 4.0 technologies. 


\section{Acknowledgement:}

Both authors contributed equally to this research.

\section{REFERENCES}

Ahmad, F. (2019). A systematic review of the role of Big Data Analytics in reducing the influence of cognitive errors on the audit judgement. Revista de Contabilidad-Spanish Accounting Review, 22(2), 187-202. https://doi.org/ 10.6018/rcsar.382251

Alkhodre, A., Ali, T., Jan, S., Alsaawy, Y., Khusro, S., \& Yasar, M. (2019). A Blockchain-based value added tax (VAT) system: Saudi Arabia as a use-case. International Journal of Advanced Computer Science and Applications, 10(5), 708716. https://doi.org/10.14569/ijacsa.2019.0100588

Alles, M. G. (2015). Drivers of the use and facilitators and obstacles of the evolution of big data by the audit profession. Accounting Horizons, 29(2), 439-449. https://doi.org/10.2308/acch-51067

Alles, M. G., \& Gray, G. L. (2020). Will the medium become the message? A framework for understanding the coming automation of the audit process. Journal of Information Systems, 34(2), 109-130. https://doi.org/10.2308/isys-52633

Appelbaum, D., Kogan, A., \& Vasarhelyi, M. A. (2017). Big data and analytics in the modern audit engagement: Research needs. Auditing, 36(4), 1-27. https://doi.org/10.2308/ajpt-51684

Astami, E. W., Rusmin, R., Hartadi, B., \& Evans, J. (2017). The role of audit quality and culture influence on earnings management in companies with excessive free cash flow: Evidence from the Asia-Pacific region. International Journal of Accounting and Information Management, 25(1), 21-42. https://doi.org/10. 1108/IJAIM-05-2016-0059

Bentley, D. (2019). Timeless principles of taxpayer protection: How they adapt to digital disruption. EJournal of Tax Research, 16(3), 679-713.

Best, S. J., \& Teske, P. (2007). Explaining State Internet Sales Taxation: New Economy, Old-Fashioned Interest Group Politics. State Politics \& Policy Quarterly, 2(1), 37-51. https://doi.org/10.1177/153244000200200103

Bonsón, E., \& Bednárová, M. (2019). Blockchain and its implications for accounting and auditing. Meditari Accountancy Research, 27(5), 725-740. https://doi.org/10.1108/MEDAR-11-2018-0406

Bonsón, E., Cortijo, V., \& Escobar, T. (2009). Towards the global adoption of XBRL using International Financial Reporting Standards (IFRS). International Journal of Accounting Information Systems, 10(1), 46-60. https://doi.org/ 10.1016/j.accinf.2008.10.002 
Bonyuet, D. (2020). Overview and impact of blockchain on auditing. International Journal of Digital Accounting Research, 20, 31-43. https://doi.org/10.4192/15778517-v20_2

Buckless, F. A., Earp, J. B., \& Ingraham, L. R. (2000). Auditing in the information age: A proposed intelligent system. New Review of Applied Expert Systems and Emerging Technologies, 6, 137-145.

Cao, M., Chychyla, R., \& Stewart, T. (2015). Big data analytics in financial statement audits. Accounting Horizons, 29(2), 423-429. https://doi.org/ 10.2308/acch-51068

Cerullo, M. J., \& Cerullo, V. (1999). Using neural networks to predict financial reporting fraud: Part 1. Computer Fraud and Security, 1999(5), 14-17. https://doi.org/10.1016/s1361-3723(99)80015-3

Cičak, J., \& Vašiček, D. (2019). Determining the Level of Accounting Conservatism through the Fuzzy Logic System. Business Systems Research, 10(1), 88-101. https://doi.org/10.2478/bsrj-2019-0007

Connell, N. A. D. (1987). Expert Systems in Accountancy: A Review of Some Recent Applications. Accounting and Business Research, 17(67), 221-233. https://doi.org/10.1080/00014788.1987.9729802

Coyne, J. G., \& McMickle, P. L. (2017). Can blockchains serve an accounting purpose? Journal of Emerging Technologies in Accounting, 14(2), 101-111. https://doi.org/10.2308/jeta-51910

Didimo, W., Giamminonni, L., Liotta, G., Montecchiani, F., \& Pagliuca, D. (2018). A visual analytics system to support tax evasion discovery. Decision Support Systems, 110, 71-83. https://doi.org/10.1016/j.dss.2018.03.008

Eining, M. M., Jones, D. R., \& Loebbecke, J. K. (1997). Reliance on decision aids: An examination of auditors' assessment of management fraud. Auditing, 16(2), 1619.

Elliott, R. K. (1986). Auditing in the 1990s: Implications for Education and Research. California Management Review, 28(4), 89-97. https://doi.org/ $10.2307 / 41165218$

Faccia, A., \& Mosteanu, N. R. (2019). Tax Evasion Information System and Blockchain. Journal of Information Systems \& Operations Management, 13(1), 6574.

Feung, J. L. C., \& Thiruchelvam, I. V. (2020). A framework model for continuous auditing in financial statement audits using big data analytics. International Journal of Scientific and Technology Research, 9(4), 3416-3434.

Friedlob, G. T., \& Schleifer, L. L. F. (1999). Fuzzy logic: Application for audit risk 
and uncertainty. Managerial Auditing Journal, 14(3), 127-137. https://doi.org/ $10.1108 / 02686909910259103$

Gamannossi degl'Innocenti, D., \& Rablen, M. D. (2020). Tax evasion on a social network. Journal of Economic Behavior and Organization, 169, 79-91. https://doi.org/10.1016/j.jebo.2019.11.001

Gao, Y., Li, M., \& Lu, Y. (2020). What Can Be Learned from Billions of Invoices? The Construction and Application of China's Multiregional Input-Output Table Based on Big Data from the Value-Added Tax. Emerging Markets Finance and Trade, 56(9), 1925-1941. https://doi.org/10.1080/1540496X.2019.1684254

Gasteiger, E., \& Prettner, K. (2020). Automation, Stagnation, and the Implications of A Robot Tax. Macroeconomic Dynamics. https://doi.org/10.1017/ S1365100520000139

Gepp, A., Linnenluecke, M. K., O’Neill, T. J., \& Smith, T. (2018). Big data techniques in auditing research and practice: Current trends and future opportunities. Journal of Accounting Literature, 40, 102-115. https://doi.org/ 10.1016/j.acclit.2017.05.003

Goryachikh, S. P., Lapteva, S. V, Matushkina, Y. N., \& Kalinin, P. A. (2019). Audit of training of digital personnel for regional economy in the conditions of Industry 4.0. On the Horizon, 27(3-4), 245-251. https://doi.org/10.1108/OTH-07-20190039

Hajek, P., \& Henriques, R. (2017). Mining corporate annual reports for intelligent detection of financial statement fraud - A comparative study of machine learning methods. Knowledge-Based Systems, 128, 139-152. https://doi.org/10.1016/ j.knosys.2017.05.001

Hansen, J. V, McDonald, J. B., \& Stice, J. D. (1992). Artificial Intelligence and Generalized Qualitative-Response Models: An Empirical Test on Two Audit Decision-Making Domains. Decision Sciences, 23(3), 708-723. https://doi.org/ 10.1111/j.1540-5915.1992.tb00413.x

Houser, K. A., \& Sanders, D. (2018). The use of big data analytics by the IRS: What tax practitioners need to know. Journal of Taxation, 128(2). Retrieved from Ionescu, L. (2019). Should governments tax companies' use of robots? Automated workers, technological unemployment, and wage inequality. Economics, Management, and Financial Markets, 14(2), 64-69. https://doi.org/ 10.22381/EMFM14220195

Jacob, V. S., \& Bailey Jr., A. D. (1991). A conceptual framework for the network approach to expert systems development in auditing. Information Processing and Management, 27(5), 481-497. https://doi.org/10.1016/0306-4573(91)90064-S

Janvrin, D. J., \& Weidenmier Watson, M. (2017). "Big Data": A new twist to 
accounting. Journal of Accounting Education, 38, 3-8. https://doi.org/ 10.1016/j.jaccedu.2016.12.009

Joshi, P. L., \& Marthandan, G. (2020). Continuous internal auditing: Can big data analytics help? International Journal of Accounting, Auditing and Performance Evaluation, 16(1), 25-42. https://doi.org/10.1504/IJAAPE.2020.106766

Kend, M., \& Nguyen, L. A. (2020). Big Data Analytics and Other Emerging Technologies: The Impact on the Australian Audit and Assurance Profession. Australian Accounting Review, 30(4), 269-282. https://doi.org/10.1111/auar.12305

Kirk, C. P., \& Rifkin, L. S. (2020). I'll trade you diamonds for toilet paper: Consumer reacting, coping and adapting behaviors in the COVID-19 pandemic. Journal of Business Research, 117, 124-131. https://doi.org/10.1016/ j.jbusres.2020.05.028

Kollmann, J. (2019). The VAT treatment of cryptocurrencies. EC Tax Review, 28(3), 164-170.

Kolsi, M. C., \& Attayah, O. F. (2018). Are socially responsible firms less engaged in earnings management? Evidence from ADX listed companies. International Journal of Business Innovation and Research, 17(4), 536-560. https://doi.org/ 10.1504/IJBIR.2018.096373

Koskinen, J., Isohanni, M., Paajala, H., Jaaskelainen, E., Nieminen, P., Koponen, H., ... Miettunen, J. (2008). How to use bibliometric methods in evaluation of scientific research? An example from Finnish schizophrenia research. Nordic Journal of Psychiatry, 62(2), 136-143. https://doi.org/10.1080/0803 9480801961667

Krahel, J. P., \& Titera, W. R. (2015). Consequences of big data and formalization on accounting and auditing standards. Accounting Horizons, 29(2), 409-422. https://doi.org/10.2308/acch-51065

La Torre, M., Botes, V. L., Dumay, J., Rea, M. A., \& Odendaal, E. (2018). The fall and rise of intellectual capital accounting: new prospects from the Big Data revolution. Meditari Accountancy Research, 26(3), 381-399. https://doi.org/ 10.1108/MEDAR-05-2018-0344

Lenard, M. J., Alam, P., \& Madey, G. R. (1995). The Application of Neural Networks and a Qualitative Response Model to the Auditor's Going Concern Uncertainty Decision. Decision Sciences, 26(2), 209-227. https://doi.org/10.1111/ j.1540-5915.1995.tb01426.x

Lin, J. W., Hwang, M. I., \& Becker, J. D. (2003). A fuzzy neural network for assessing the risk of fraudulent financial reporting. Managerial Auditing Journal, 18(8), 657-665. https://doi.org/10.1108/02686900310495151 
Manita, R., Elommal, N., Baudier, P., \& Hikkerova, L. (2020). The digital transformation of external audit and its impact on corporate governance. Technological Forecasting and Social Change, 150. https://doi.org/ 10.1016/j.techfore.2019.119751

Merkx, M. (2019). VAT and blockchain: Challenges and opportunities ahead. EC Tax Review, 28(2), 83-89.

Mohamad, S., Abdurrahman, A. P., \& Keong, O. C. (2020). Blockchain technology: Implications for accountants. International Journal of Innovation, Creativity and Change, 10(11), 101-117.

Moll, J., \& Yigitbasioglu, O. (2019). The role of internet-related technologies in shaping the work of accountants: New directions for accounting research. British Accounting Review, 51(6), 20-. https://doi.org/10.1016/j.bar.2019.04.002

Muñoz-Izquierdo, N., Camacho-Miñano, M.-M., Segovia-Vargas, M.-J., \& Pascual-Ezama, D. (2019). Is the external audit report useful for bankruptcy prediction? Evidence using artificial intelligence. International Journal of Financial Studies, 7(2), 20-44. https://doi.org/10.3390/ijfs7020020

Paltrinieri, A., Hassan, M. K., Bahoo, S., \& Khan, A. (2020). A bibliometric review of sukuk literature. International Review of Economics and Finance. https://doi.org/10.1016/j.iref.2019.04.004

Pei, D., \& Vasarhelyi, M. A. (2020). Big data and algorithmic trading against periodic and tangible asset reporting: The need for U-XBRL. International Journal of Accounting Information Systems, 37. https://doi.org/10.1016/j.accinf. 2020.100453

Politou, E., Alepis, E., \& Patsakis, C. (2019). Profiling tax and financial behaviour with big data under the GDPR. Computer Law and Security Review, 35(3), 306329. https://doi.org/10.1016/j.clsr.2019.01.003

Rose, A. M., Rose, J. M., Sanderson, K.-A., \& Thibodeau, J. C. (2017). When should audit firms introduce analyses of big data into the audit process? Journal of Information Systems, 31(3), 81-99. https://doi.org/10.2308/isys-51837

Rozario, A. M., \& Thomas, C. (2019). Reengineering the audit with blockchain and smart contracts. Journal of Emerging Technologies in Accounting, 16(1), 21-35. https://doi.org/10.2308/jeta-52432

Ruan, J., Yan, Z., Dong, B., Zheng, Q., \& Qian, B. (2019). Identifying suspicious groups of affiliated-transaction-based tax evasion in big data. Information Sciences, 477, 508-532. https://doi.org/10.1016/j.ins.2018.11.008

Rushinek, A., \& Rushinek, S. F. (1986). Statistical/mathematical software related to computer user satisfaction: An interactive online expert system using diagnostic 
audit trails through telecommunication networks. International Journal of Mathematical Education in Science and Technology, 17(3), 285-303. https://doi.org/10.1080/0020739860170304

Schmitz, J., \& Leoni, G. (2019). Accounting and Auditing at the Time of Blockchain Technology: A Research Agenda. Australian Accounting Review, 29(2), 331-342. https://doi.org/10.1111/auar.12286

Seglen, P. O. (1989). Evaluation of scientific quality using citation analysis and other bibliometric methods. Nordisk medicin, 104(12), 331-5.

Shaffer, K. J., Gaumer, C. J., \& Bradley, K. P. (2020). Artificial intelligence products reshape accounting: time to re-train. Development and Learning in Organizations. 34(6), 41-43. https://doi.org/10.1108/DLO-10-2019-0242

Shnaider, E., \& Kandel, A. (1992). A system for forecasting corporate-tax revenue based on fuzzy logic and fuzzy set theory. Information Sciences, 63(1-2), 11-31. https://doi.org/10.1016/0020-0255(92)90060-L

Shukla, M., \& Mattar, L. (2019). Next generation smart sustainable auditing systems using Big Data Analytics: Understanding the interaction of critical barriers. Computers and Industrial Engineering, 128, 1015-1026. https://doi.org/ 10.1016/j.cie.2018.04.055

Smith, S. S., \& Castonguay, J. J. (2020). Blockchain and accounting governance: emerging issues and considerations for accounting and assurance professionals. Journal of Emerging Technologies in Accounting, 17(1), 119-131. https:// doi.org/10.2308/jeta-52686

Sobotka, P., \& Vrana, I. (2007). Automatic on-line risk analysis of suspicious transactions. Agricultural Economics, 53(12), 558-564. https://doi.org/10. 17221/1221-agricecon

Sun, T. S. (2019). Applying deep learning to audit procedures: An illustrative framework. Accounting Horizons, 33(3), 89-109. https://doi.org/10.2308/acch52455

Tang, J., \& Karim, K. E. (2019). Financial fraud detection and big data analytics implications on auditors' use of fraud brainstorming session. Managerial Auditing Journal, 34(3), 324-337. https://doi.org/10.1108/MAJ-01-2018-1767

Tian, F., Lan, T., Chao, K.-M., Godwin, N., Zheng, Q., Shah, N., \& Zhang, F. (2016). Mining suspicious tax evasion groups in big data. IEEE Transactions on Knowledge and Data Engineering, 28(10), 2651-2664. https://doi.org/10.1109/ TKDE.2016.2571686

Tiberius, V., \& Hirth, S. (2019). Impacts of digitization on auditing: A Delphi study for Germany. Journal of International Accounting, Auditing and Taxation, 37. 
https://doi.org/10.1016/j.intaccaudtax.2019.100288

Wang, P. (2017). A study on the tax system based on the data mining. Agro Food Industry Hi-Tech, 28(3), 2580-2583.

Wang, S., Ha, J., Kalkavan, H., Yüksel, S., \& Dinçer, H. (2020). IT2-Based Hybrid Approach for Sustainable Economic Equality: A Case of E7 Economies. SAGE Open, 10(2), 1-22. https://doi.org/10.1177/2158244020924434

Wensley, A. (1986). An expert systems approach to audit planning. ACM SIGMIS Database, 17(4), 50. https://doi.org/10.1145/1113523.1113542

West, J., \& Bhattacharya, M. (2016). Intelligent financial fraud detection: A comprehensive review. Computers and Security, 57, 47-66. https://doi.org/ 10.1016/j.cose.2015.09.005

Yoon, K., Hoogduin, L., \& Zhang, L. (2015). Big data as complementary audit evidence. Accounting Horizons, 29(2), 431-438. https://doi.org/10.2308/acch51076

Zhang, J., Yang, X., \& Appelbaum, D. (2015). Toward effective big data analysis in continuous auditing. Accounting Horizons, 29(2), 469-476. https://doi.org/ 10.2308/acch-51070

Zhang, P. (2019). Automation, wage inequality and implications of a robot tax. International Review of Economics and Finance, 59, 500-509. https://doi.org/ 10.1016/j.iref.2018.10.013

Zhang, Y. J. (2018). Model innovation and teaching effect evaluation of accounting teaching in higher vocational colleges in the era of big data. Kuram ve Uygulamada Egitim Bilimleri, 18(6), 3620-3627. https://doi.org/10.12738/estp.2018.6.274 